\title{
A Review of Research on the Influencing Factors of China's Corporation Debt Leverage
}

\author{
Jiaming Lin \\ $\mathrm{PhD}$ candidate \\ School of Economics, Central University of Finance and Economics \\ No. 39 South College Road, Haidian District, Beijing \\ China
}

\begin{abstract}
Under the background of economic transformation of China, how to adjust the "leverage" and "growth" has become a hot topic of academic research. Existing studies have discussed the issues such as the leverage level, leveragestructure and impact of China 's financial stability. This article mainly analyzes the influencing factors and research methods of corporationdebt leverage, and introduces the chain reaction of corporation debt sustainability and financial stability. The formation of the structural characteristics of Chinese corporation debt leverage is complex, in the process of steady adjustment, a structural approach should also be used, especially in the context of financial deepening. Researches on the relationship between debt leverage and economic growth needs to pay more attention to the efficiency of corporate capital output and debt sustainability.
\end{abstract}

Keywords: Influencing factorsChina's corporation debt leverage

\section{Introduction}

After the outbreak of the financial crisis, the topics surrounding the financial crisis and the debt crisis aroused the interest of many scholars. Debt leverage, economic cycles, monetary policy, credit scale, shadow banking and other factors are intertwined, making the problem of debt leverage more complicated. Facing the downward pressure of the global economy and the pressure of economic structural transformation, excessive debt leverage has become a prominent issue in China's current economic development. According to BIS (International Settlement Bank) statistics, as of the third quarter of 2018, the leverage ratio of China's real economy macro debt was $252.7 \%$, an increase of about $110 \%$ compared to 2008 , especially the non-financial corporate sector leverage ratio was $152.9 \%$, an increase of about $55 \%$ over 2008. We concerned about the reasons of the rapid rise in debt leverage of Chinese companies and the influencing factors of this problem, and what is the relationship between debt leverage and financial risks.In order to answer these questions, this paper will review the influencing factors and research methods of enterprise debt leverage of existing studies, andgive some suggestions for improvement. The structure of the article is as follows: the second part is the introduction of the characteristics of corporate debt. The third part is the review about theanalysis of influencing factors of China's corporation debt. The fourth part is the reviewof sustainability of debt leverage from a financial risk perspective. The fifth part is conclusion.

\section{The Characteristics of China's corporation debt}

\subsection{Definition of debt leverage}

From a macro perspective, it is commonly used to measure total debt / GDP to facilitate horizontal international comparisons (BIS, 2011; IMF, 2015; People's Bank of China Leverage Research Group, 2014; Li Y, 2015, etc.). From a micro perspective, the debt leverage ratio (that is, the asset-liability ratio) reflects the ratio of borrowed capital of the company to its own capital. The leverage ratio is high, indicating that the company has more borrowed capital than its own capital. It is basically the same that when discussing the issue of debt leverage from the perspective of the business sector, the debt leverage ratio indicator is used corporation debt leverage ratio= total corporate debt / GDP; when discussing the issue of debt leverage from a certain corporate, the debt leverage ratio is used the asset-liability ratio $=$ liability / asset.

\subsection{Characteristics of China's corporation debt leverage}

\subsubsection{China's macro debt situation}

Since the US subprime mortgage crisis in 2008, China 's macro debt leverage has shown an upward trend as a whole (Figure 1). According to BIS (International Settlement Bank) statistics, as of the third quarter of 2018, the leverage ratio of China's real economy macro debt was $252.7 \%$, an increase of about $110 \%$ compared to 2008 . Among them, the 
non-financial corporate sector leverage ratio was $152.9 \%$, an increase of about 55\% over 2008. After decomposing, it is found that the high leverage ratio of China's macro debt is mainly reflected in the non-financial corporation sector. The debt contradictions of the non-financial corporation sector are mainly reflected in the heavy chemical industry and state-owned enterprises.

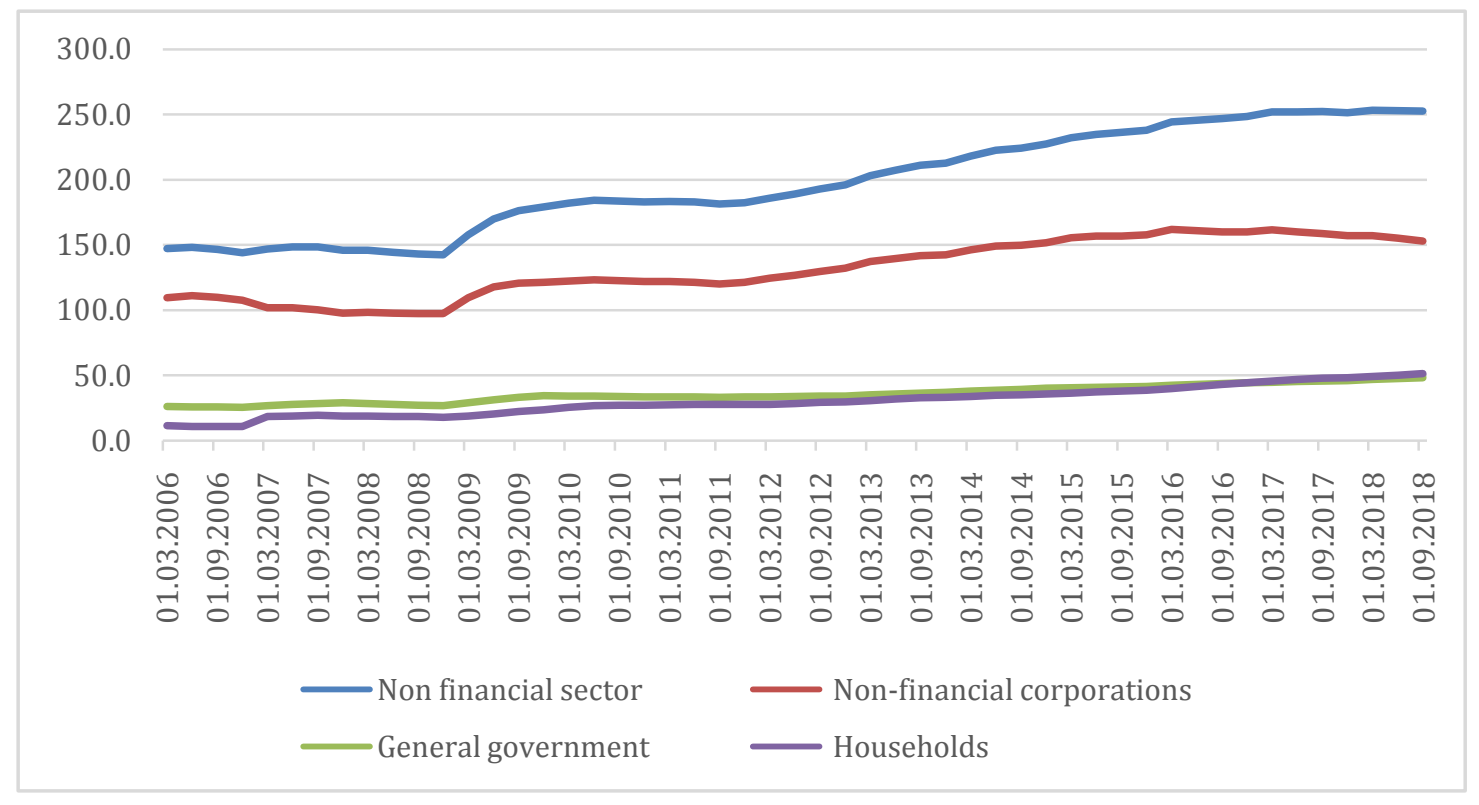

Data source: BIS

Figure 1 Macro Debt Trend of China's Real Economy (2006-2018)

2.2.2 The structural contradictions of corporation debt are prominent

Along the structural decomposition, Chen W and Xiong Q (2017), Yu C (2017), Xu Z (2017), Yang G (2018) and other studies found that the structure of China's non-financial corporation debt leverage is also reflected in the industry, Geographical and corporation ownership attributes. For example, from the point of view of whether it is a listed company, the listed non-financial enterprises and non-listed non-financial enterprises have higher leverage ratios. From the perspective of corporate ownership, state-owned enterprises have higher leverage ratios than private enterprises (Figure 2). In terms of industry attributes, the leverage ratio of the industry, materials, utilities and energy industries is relatively high (Figure 3); geographically, the west region has a higher leverage ratio (Figure 4). In general, the structural contradiction of China's non-financial corporation debt is an indisputable fact. This structural contradiction also determines that the policy cannot adopt a "one size fits all" strategy in the process of "de-leveraging".

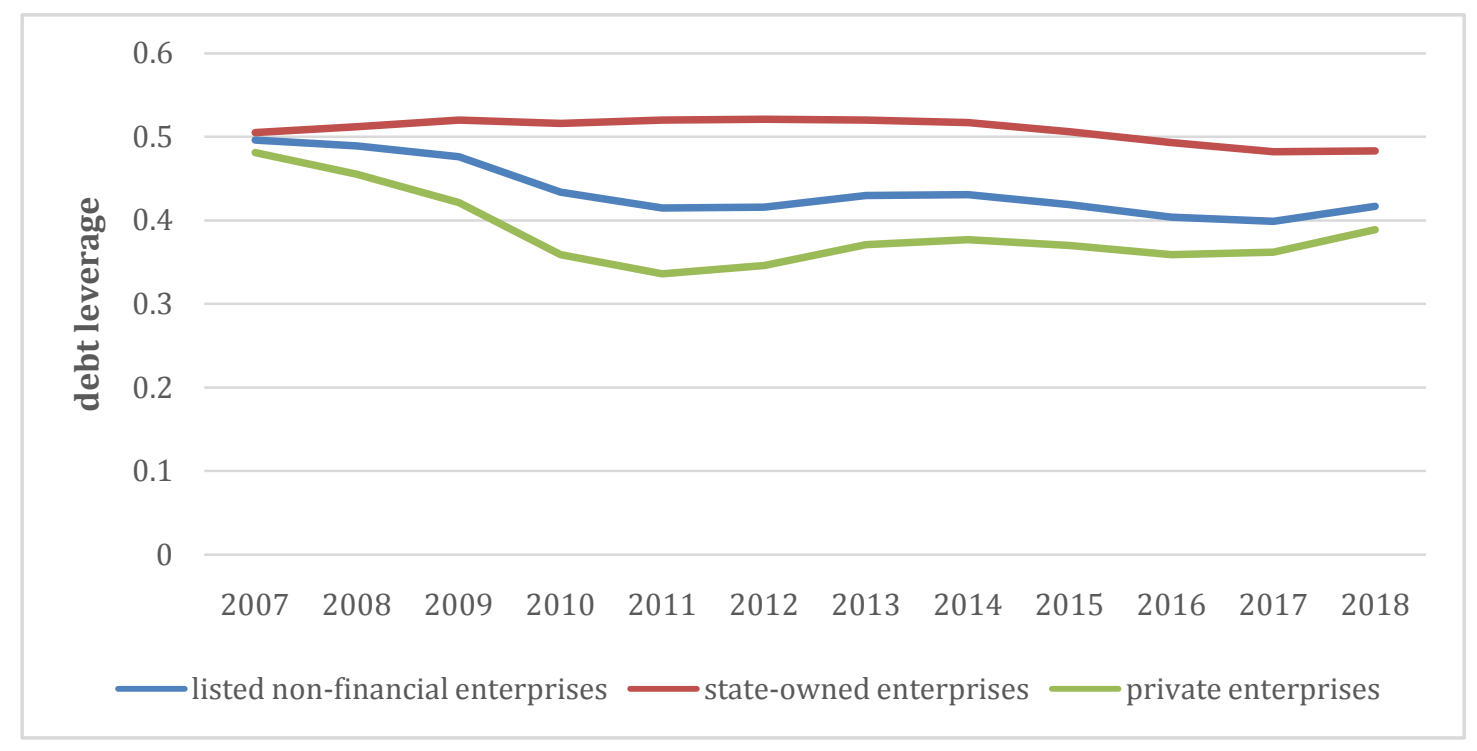


Figure 2 Listed company debt leverage trend: state-owned companies and private companies (2007-2018) Data source: Guotai'an Database

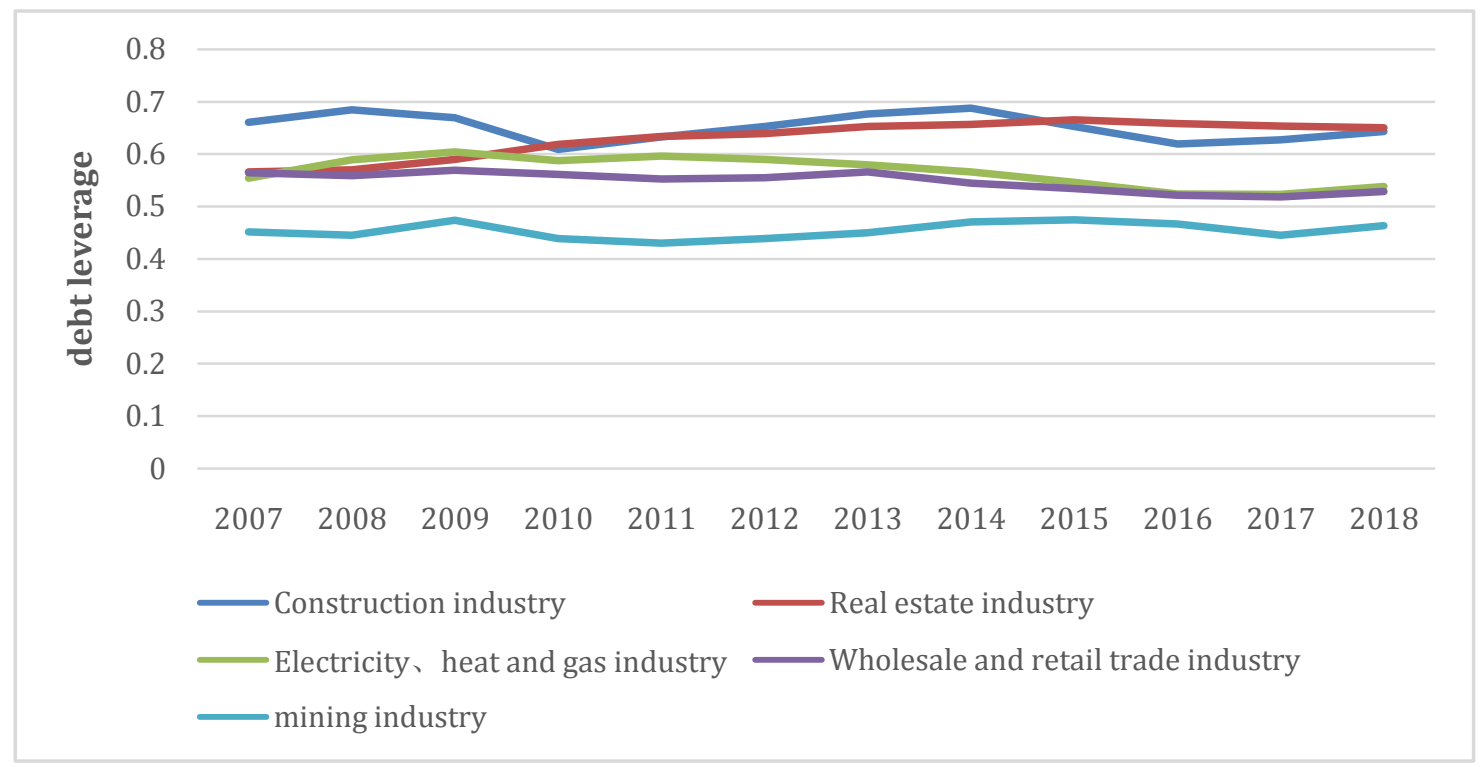

Figure 3 Different industries debt leverage trend (2007-2018)

Data source: Guotai'an Database

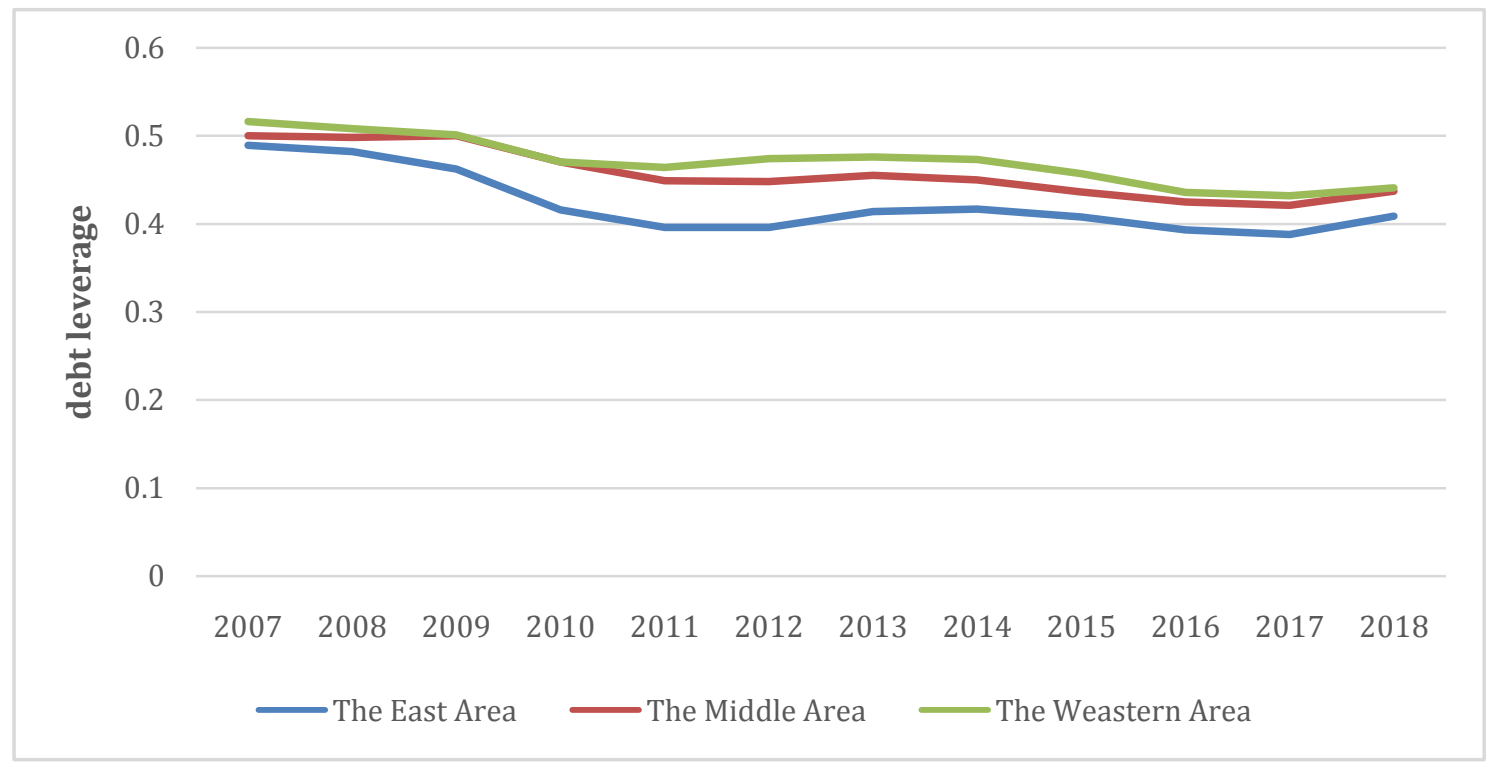

Data source: Guotai'an Database

Figure 4 Different areas debt leverage trend (2007-2018)

\subsubsection{Default of corporate bonds}

Firstly, the number and scale of corporate bond defaults are large. According to GuotaiJunan's April 2019 research report, from January 2018 to the end of April 2019, a total of 183 bonds in China have defaulted, involving an amount of 156.91 billion yuan. Secondly, the default rate of defaulting private corporate bonds is low. Of the 183 bonds that have defaulted since 2018, a total of 133 defaulted bonds are private corporate bonds, involving an amount of 78billionyuan, accounting for $72.68 \%$ of the total amount and $49.71 \%$ of the total amount. Among them, a total of 122 bonds out of the above 133 private corporate defaulted bonds have not been redeemed yet, and the redemption rate is 
only $8.27 \%$. From the above data, it is not difficult to find that since 2018 , private corporate bonds have shown a multiplying growth trend in both the number of defaults and the amount of defaults. However, the redemption rate of debts has declined significantly. In this regard, we can't help worrying about whether the debt problem of private enterprises is sustainable? Will it intensify in the process of "deleveraging" and trigger a debt crisis?

\section{Influencing factors of China's corporation debt}

The above analysis shows the basic situation of the debt leverage of Chinese corporations: the overall debt leverage ratio is relatively high (compared to theother macroeconomic sectors) and it has the structural characteristics. In this regard, we would like to explore what causes this phenomenon? The existing literatures on the factors affecting debt leverage is very rich.In the following parts, we will separate them into four categories: economic growth, monetary policy, financial development and enterprise operations.

\subsection{Economic growth and corporation debt leverage}

The relationship between economic growth and corporation debt leverage is still under open discussion, but it is certain that the two are not a simple linear relationship. Regarding the impact of economic growth on corporation debt leverage, trade-off theory holds that when a country's GDP growth rate is higher, companies have higher levels of profitability, tend to use debt financing, and corporation debt leverage will also increase. Empirical results also validate this view (Tan X et al., 2018; Yang G, 2018, etc.). On the other hand, regarding the impact of debt leverage on economic growth, the following two options can be summarized: the first, under certain conditions, debt drives economic growth. Keynes(1936) pointed out that in the case of insufficient effective demand, the government can use fiscal policies to stimulate the economy by increasing public debt, increase employment opportunities, and promote economic growth. Okun, Tobin, Samuelson and others also believe that in the state of underemployment, deficits and debt can positively affect the control of income, aggregate demand and even output. Chen D (2019) explained from the perspective of credit that the credit-driven economic growth mechanism is that credit uses physical activities to increase the drive for investment and consumption, that is, to promote capital formation and expand final consumption, thereby bringing economic growth; Liu X et al. (2015) Believes that credit growth can exert positive effects on economic development through income effects and investment effects. Rajan and Zingales (1998) believe that when the leverage level is low, the increase in debt leverage can promote the optimization of social resource allocation and have a greater promotion effect on economic growth. When borrowing money, excessive leverage will drive up asset prices, making the structure of the financial system increasingly fragile, and easily putting the economy into a "debt-deflation" vicious circle when financing constraints are tightened (Minsky, 1992). The second, the impact of debt on economic growth is non-linear. Ma Y and Chen Y (2017) believe that the effect of leverage on economic growth has a significant "inverted U-shape" characteristic. As the level of leverage increases, the economic growth rate will increase first and then decrease. Li Y et al. (2012) believe that there is an optimal level of debt leverage. Before reaching the optimal level, rising leverage can drive economic growth, and exceeding the optimal level will lead to a financial crisis. Liu X, Liu Y, Wang J (2018) believe that the impact of leverage on economic growth is dynamic. When the economic growth rate is below a certain threshold, the leverage is not conducive to economic growth and increases the probability of economic recession. However, when the economic growth rate exceeds this threshold, the leverage ratio can promote economic growth.

When studying the impact of economic growth and debt leverage, the mainstream methods include: differential GMM estimation and systematic GMM estimation, vector error correction model (VECM), panel vector autoregressive model (PVAR), time-varying parameter vector autoregression (TVP-VAR) Models, etc. For example, Ma Y and Chen Y (2017) examined the impact of financial leverage and its fluctuations on economic growth using a systematic GMM method; Sun S and Wu S (2019) used the VECM model to study the impact of debt leverage levels on economic growth in different sectors of China, and an impulse response analysis was performed to find that the increased leverage of enterprises has a positive effect on China's economic growth; Jiang H et al. (2019)use panel vector autoregressive model (PVAR) to empirically study the dynamic non-linear correlation between the level of the real economy's leverage ratioand economic growth, and find that the current economic growth has an impact on the overall leverage of the real economy in the future, and household leverage There is a significant negative impact on the rate of leverage and government leverage, and the effect on the leverage of non-financial companies is not significant; Ma Y and Zhang J (2019) using TVP-VAR model,systematically investigated the leverage of the four sectors, and tested the sustainability of the leverage ratio of various sectors from the perspective of output effects and potential risks, and found that excessively rapid growth of leverage ratio will increase asset price volatility, increase financial instability, and weaken leverage ratio to increase output. 
Through the above analysis, we can find that the research on economic growth and corporation debt leverage is still more controversial. Different assumptions and different methods of argument will lead to different conclusions. In the context of financial deepening, this topic can also lead to more research directions, such as what is the relationship between corporation debt leverage and economic growth show when adding asset price volatility?

what kind of response will happen between corporation debt leverage and economic growth under the stimulation of different policies and so on.

\subsection{Monetary policy and corporation debt leverage}

The study of leverage from the perspective of monetary policy can be roughly summarized into the following three perspectives: the first, the credit expansion caused by the expansion of the base currency, specifically, the loose monetary environment and the enthusiasm for investment in the corporation sector lead to an increase in credit scale. The second, debt financing accounts for a relatively high proportion in the social financing structure. On the one hand, in developing countries where the level of financial development is not high and the legal environment is not sound, entity companies tend to use debt financing, which leads to a rise in the proportion of debt; on the other hand, in countries dominated by the banking system, the financial sector also The tendency is to lend funds to companies with good credit qualifications, many mortgage guarantees, but possibly average asset returns to obtain stable returns, and also increase the debt scale of the non-financial corporation sector. The third is the uneven distribution of resources among the macroeconomic sectors, which is commonly referred to as the "soft budget constraint", which is mainly manifested in the high debt leverage ratio of the state-owned enterprises in the corporate sector. The scale of its financing in the financial sector. In general, from the perspective of monetary policy, the increase in debt leverage of non-financial companies cannot be separated from the impact of monetary policy adjustments and the allocation of financial resources.

Based on the above-mentioned monetary policy's impact on the formation of a high debt leverage ratio, there is currently no unified conclusion. An explanatory view is that the impact of loose monetary policy on debt leverage is positive. Bauer and Granziera (2017) explored the impact of monetary policy shocks on leverage based on data from developed countries. Tighter monetary policy will lead to an increase in leverage in the short term, and in the long run, the rise in capital costs will weaken the willingness to borrow and further promote Leverage has fallen. Alter and Elekdag (2016) based on the data from non-financial companies in emerging market countriesfound that the loose monetary policy implemented in the United States will cause the leverage of emerging market countries to rise. Wang A and Du Q (2017) analyzed the impact of the money supply and interest rate shocks on the leverage ratio starting from the transmission mechanism of monetary policy and economic growth: an increase in the money supply will lead to an increase in output while also leading to an increase in leverage. Rapidly rising; while the increase of interest rates can restrain the increase of leverage in the short term, it will cause the leverage to rise again in the long run; meanwhile, the money supply has a greater impact on the change of leverage than the interest rate. Another interpretation is that the impact of loose monetary policy on debt leverage is negative. Song G (2014) analyzed the impact of monetary policy on M2 / GDP from the perspective of procyclical currency circulation, and summarized it as the "less and more currency" phenomenon, that is, when the implementation of active monetary policy increases M2, the increase in GDP may be more Faster, making M2 / GDP fall; when implementing a tight monetary policy, GDP may fall faster than M2, making M2 / GDP rise instead. Liu X and Zhang J (2016) analyzed the relationship between money supply and leverage through a modified DSGE model. The study found that under the financial accelerator effect, the rise of M2 is more likely to cause rapid rise in asset prices (such as housing prices). The expansion of investment and consumption channels to boost GDP has led to a decline in leverage. From the perspective of debt efficiency alone, some scholars believe that tightening deleveraging may bring debt liquidity risks, and eventually trigger "debt-deflation" risks (Ji M, etc., 2018). From the debate about whether monetary policy should be "loose" or "tightening", the first view is easier to understand. The transmission of loose monetary policy through various monetary intermediate indicators (such as interest rates, exchange rates, etc.) will stimulate the adoption of non-financial corporation sectors. Borrowing debt yields higher returns; the second view is from the liability end of the financial system, that is, the impact of bank deposits on the change in the overall macroeconomic leverage ratio as a result of credit origination. Combined with China's "clear and tight" monetary policy environment in recent years, the existence of the "leverage paradox" can be confirmed from the side. Therefore, whether it is loose or tightening monetary policy, the effect of reducing the leverage of debt by adjusting the aggregate amount of nominal currency may be limited. Solving the problem of rising debt leverage may not place too much hope on the total amount of monetary debtmanagement. In addition, some scholars believe that the effect of monetary policy regulation on debt leverage has little effect. Yang $\mathbf{J}$ and Gao $\mathrm{H}$ (2016) pointed out that loose monetary policy may bring asset bubbles and offset the role of expansionary monetary policy in promoting the real economy. 
The implementation of the policy cannot achieve the effect of promoting economic growth and increasing the denominator. Hu Z (2014) introduced both "decreasing leverage" and "stable growth" as policy objectives to introduce the optimal decision-making of monetary authorities. The study found that the effect of regulating the growth rate of the money supply to reduce leverage was not ideal, and the policy effect was Unstable and highly susceptible to other factors; Liu J and Chen D (2017) used the TVP-VAR model to study the dynamic mechanism of macro leverage, economic growth, and monetary policy and found that austerity monetary policy affects macro leverage, There are both positive and negative effects. On the one hand, it will cause a small increase in macro leverage, which is not conducive to "reducing leverage." Although monetary policy cannot reduce the debt leverage ratio, it can reduce the rate of debt leverage climbing and achieve the effect of "stabilizing leverage".

When studying the impact of monetary policy on debt leverage, the mainstream analysis methods are mainly DSGE (Hu Z, 2014; Liu X et al., 2016; Zhou J et al., 2018; Luo Y, Chen B, 2018, etc.) and the balance sheet method (Xiao Q, 2010; Liu Y, 2017, etc.). In the use of the DSGE model, scholars mostly analyze the impact of monetary policy on major economic variables by establishing multi-sector macroeconomic models; the Balance Sheet Approach analysis method can connect the assets and liabilities of various macroeconomic sectors, and can more clearly reveal the interaction between various departments. It is often used in the analysis of systemic risk transmission. In addition, another advantage of applying asset-liability analysis is that the reason for the high leverage of China's macro debt is the rising debt of non-financial companies. Corporate debt is mostly used for investment, and assets will be formed in the future, so debt analysis linked to assets is more logical (Li Yang, 2016).

\subsection{Financial development and corporation debt leverage}

The fact that monetary policy affects the availability of credit through the money supply and then the debt leverage of the non-financial corporation sector is straightforward. In addition, scholars have also found that along with financial innovation and development, the financialization of non-financial companies and the development of shadow banking have also greatly affected the debt leverage of non-financial companies. The first is the impact of financialization of non-financial companies. The first thing needto understand is what is the logic of financialization of non-financial companies? What is the purpose of "financialization"? Demir (2009) believes that the allocation of large amounts of funds to highly virtualized financial assets by real entities is called "financialization" and can be measured by the proportion of corporate financial assets in total assets. Regarding the reasons for the financialization of enterprises, there are two mainstream views. One view is that companies hold necessary financial assets in order to invest in the real economy, which is a preventive action, such as alleviating financial distress (Hu Y et al., 2017 ), Hedging price risk, etc .; another point of view is that based on the difference between the real economy investment and financial investment returns, companies choose financial investment to maximize returns (Xie J et al., 2014; Zhang C and Zhang B, 2016, etc.) Speculation. Regardless of the consideration, in the context of "economic financialization", does the financialization of non-financial companies have a significant impact on the rise in debt leverage? Yuan $\mathrm{G}$ and Guo $\mathrm{C}$ (2019) based on the semi-annual financial data of China-Shanghai and Shenzhen A-share listed companies from 2007 to 2017 as the research object, and found that the increase in the level of financialization of non-financial companies will exacerbate the excessive debt level of enterprises. The performance of state-owned enterprises is more obvious; however, research by $\mathrm{Wu} \mathrm{J}$ and Chen L (2018) found that there is a significant negative correlation between the degree of financial asset allocation ratio and leverage ratio of listed companies, rather than the degree of financial asset allocation ratio and leverage ratio of listed companies There is a significant positive correlation between them.

The second is the impact of shadow banking. According to the definition of the Financial Stability Board (FSB), shadow banking can be broadly described as a credit intermediary system composed of institutions and businesses outside the formal banking system, and in a narrow sense, a credit intermediary system composed of non-bank institutions . After the subprime mortgage crisis, people began to pay attention to the risks that shadow banking may bring. From the actual situation in China, shadow banking can be expanded into a circumvention arbitrage tool used to solve the contradiction between the needs of investment and financing parties in the market. In recent years, the China Banking Regulatory Commission has continued to pay attention to the regulatory arbitrage behavior of financial institutions in the shadow banking business, and has issued a series of specific requirements, reminding financial institutions to pay attention to theexpansion of shadow banking. In terms of its impact on non-financial companies, He $\mathbf{J}$ (2013) believes that the profit-seeking nature of shadow banking funds is not conducive to the development of the real economy and is likely to cause the business model of the company to be "de-relied to false"; Zhang P (2014) found shadow banking allocated too much capital to non-productive areas, which has caused an imbalance in the allocation of financial resources. Chen L et al. (2018) proceeded from the structural characteristics of corporate sector leverage, and found that the formation of the structural characteristics of corporate sector leverage is not only related to the rapid decline in profits of high-risk enterprises, but also to the higher financing costs of high-risk enterprises from shadow banks. 
Drawing on the experience of the US subprime mortgage crisis, Liu L and Ma S (2018) believe that shadow banking will trigger radical asset securitization of financial institutions, and excessive leverage will cause debt inflation and even trigger a crisis. The third is the impact of business cycles. Some scholars believe that the formation of high debt leverage is closely related to the economic cycle. Liu Y (2018) found that the rise in macro leverage is in accordance with the natural law of economic development, and the impact of monetary policy is actually the tendency of macro leverage to fluctuate around it. Excessive tightening of monetary policy will lead to more High leverage. Xiao Q (2010) believes that the debt leverage ratio has obvious procyclical characteristics, and this change is mainly consistent with the expansion and contraction of the balance sheet. Fang X (2015) analyzed the current economic cycle and debt cycle stage, and believed that the high leverage of non-financial companies may continue to invent the Minsky moment if they continue to rise. Ji M et al. (2017) analyzed the phenomenon of inconsistency between the changes in microleverage ratio and macro-leverage ratio and business cycle fluctuations after being stimulated by innovations such as technological progress, based on Juglar's research. The specific manifestation is that the micro-leverage ratio will be related to the business cycle is consistent, while the macro leverage ratio may diverge due to the lag during the expansion and recession periods.

Some scholars have also analyzed from other perspectives of financial development. For example, the research group of the Business Management Department of the People's Bank of China (2017) found from the perspective of soft budget constraints that the excessively high leverage ratio of non-financial corporate sectors is largely related to soft budget constraints ( That is, the failure of financial institutions to adhere to commercial agreements has caused the use of corporate funds to exceed their current returns), and the degree of distortion is closely related to government guarantees. Tan X et al. (2019) analyzed the financial data of non-financial listed companies in 47 countries and regions from 2000 to 2015 and found that there is a negative correlation between financial structure and corporation leverage. When the degree of marketization of financial structure is higher, companies Leverage will also decrease. And this effect is more significant in companies with high leverage, large scale, low profitability, low equity concentration, and weak government-enterprise linkages.

In empirical evidence of the influence of financial development factors on the leverage ratio of non-financial corporations, the methods used in the existing literature are mainly focused on mainstream methods in macro research, including DSGE, SVAR, DAG, and so on. For example, Wu Y and Du Q (2018) linked the major macroeconomic variables such as monetary policy adjustment, financial system development, and economic cycle changes to debt leverage, using a directed acyclic graph combined with structural vector autoregression (DAG-SVAR) model pairing. An empirical analysis of the influencing factors of China's debt leverage shows that the increase in money supply, the expansion of the financial system, the economic growth rate and the decline in profitability are the main factors for China's debt leverage to rise. Lu S and Zhao D (2019) used the DSGE method to study the transmission mechanism of monetary policy, inter-bank market interest rates, and shadow banks, and found that an increase in market interest rates will lead to an increase in the size of shadow banks and an increase in the leverage of the financial system. Chen L et al. (2018) used the Bayesian VAR method to estimate the impact of interest shocks on the leverage ratio of companies with different debt structures.

\subsection{Enterprise operations and corporation debt leverage}

The first, there is an inverse relationship between the company's own operating efficiency and debt leverage. Ma $\mathbf{J}$ et al. (2016) found that excessive corporation leverage is closely related to the inefficient use of corporate funds. When an enterprise is inefficient and has overcapacity, it can only borrow new debt to pay off the old debt. As a result, it can only have fewer and fewer effective assets. A situation where capital and liabilities are ineffective and occupied will be raised to increase the level of corporation leverage. He J and He L (2016), Bu D, etc. (2017) believe that excess capacity and the increase in leverage are in the same direction, and the increase in leverage will cause further inefficient production capacity, resulting in the overcapacity and leverage. Jiang H and Zhang Y (2017) found that the enhancement of the company's own capabilities and the improvement of the overall industry boom have a negative inhibitory effect on the company's asset-liability ratio. Lu T and Yu Y (2015) believe that the reason for the high debt leverage ratio of non-financial companies is that China's capital-to-output ratio has risen and corporate profitability has fallen. The second, there are structural differences in the debt leverage of non-financial companies. Zhong $\mathrm{N}$ et al. (2016) focused on the structural characteristics of the debt ratio of industrial enterprises above designated size and found that the debt ratio of state-owned enterprises is significantly higher than that of private enterprises. The debt ratio of private enterprises basically conforms to the principle of marketization, while the debt ratio of state-owned enterprises reflects the more obvious "non-marketization" characteristics. Yang G (2018) also analyzed the structural characteristics of non-financial companies from the perspective of bank credit placement, and found that bank new loans are more inclined to lend to state-owned enterprises with more mortgageable assets, which has increased leverage 
gaps between heterogeneityfirms. Tan X et al. (2018) used A-share listed companies from 2002 to 2015 as a sample to measure the leverage ratio of micro variables and macro variables on Chinese non-financial enterprises.

It was found that the leverage ratio of non-financial enterprises was differentiated before and after the financial crisis, and there was differentiation between state-owned enterprises and non-state-owned enterprises, and that the excessively high leverage ratio of state-owned enterprises is the key to the current debt problem of non-financial enterprises.

In this part of the research, the main research methods can be roughly divided into three categories: the first category is to consider only enterprise-level factors: such as Chen W, Xiong Q (2017); Lu T, Yu Y (2015); Zhong N and others (2016); Yang G, (2018) and others at the micro level, mainly based on statistical analysis or fixed-effect regression methods to study important characteristics of enterprises (such as fixed assets ratio, tax rate, non-debt tax shield, interest protection multiples, company size, Changes in the return on net assets, etc.) on the structural impact of nonfinancial corporation debt; the second is to consider macro-level factors, such as Hong C and Xu C (2018) borrowed from "general to special" dynamic modeling methods ( Henry, 1995; Kang J et al., 2012; Wu G, 2011), using macroindicators (such as inflation rate, economic growth rate, consumer price index, money supply, etc.) to establish longand short-term equations that affect Chinese non-financial corporation debt, The way to calculate the difference of long-term equation by $\mathrm{P}$ transform and increase the multi-order lag term, to study whether the changes in debt levels in the short term will be sustained by macro factors. The third category is the synthesis of macro and micro factors, using panel data for consideration. For example, Tan X (2018) comprehensively considered the impact of macro and micro explanatory variables, using fixed effect model analyzes the data of A-share listed companies from 2002 to 2015; Feng $\mathrm{X}$ et al. (2013) used a combination of enterprise-level factors, industry characteristics, and monetary policy and economic growth to study its impact on the debt levels of manufacturing listed companies.

Through the above analysis, it can be found that in the process of studying the influencing factors of corporation debt, the company's own operating conditions and the changes in these factors in the time series cannot be ignored. It is obvious that the panel data is more convincing than the cross-section data, covering the analysis framework of macromicro factors is more complete than the analysis framework containing only micro or only macro. From the above analysis, we can also see that scholars have two shortcomings in the analysis of the debt structure of non-financial companies: Firstly, when discussing the impact of corporate operating efficiency on the debt structure, there is less analysis of the use of macro-level factors; Secondly, when analyzing the heterogeneity of the debt structure of nonfinancial corporations, only the differences in corporate ownership and the industry in which they are located are analyzed. There are almost no other structural features involved. This is also the direction that we can continue to study in the future.

\section{Sustainability of debt leverage and financial stability}

Based on the complex linkage mechanism of the causes of China 's macro debt leverage, the issue of corporation debt leverage needs to be analyzed from multiple perspectives. In the process of steadily reducing leverage, we must not only recognize structural issues but also pay attention to debt sustainability issues.Debt sustainability refers to the state in which the borrower is able to repay debt without major adjustments to its future balance sheet (IMF, 2002). In short, debt sustainability is the ability to maintain debt balance without credit Default risk. From the perspective of microsummation: when the rate of return on assets or return on investment is greater than the cost of financing, companies in economic activities tend to run debt, which is not only profitable, but also maintains debt balance; when the rate of return on assets is less than the cost of financing, debt management will face a crisis of living beyond its means. Therefore, for policy control to "steadily reduce leverage," not only need to take structural measures, but also need to start from the perspective of maintaining debt sustainability, from the perspective of being able to adjust the return on investment and financing costs, so that the corporate sector does not have a serious risk of default. Therefore, leverage itself is not a problem, and leverage efficiency is the key point (Ji M et al., 2017). In this regard, we will focus on two aspects, one is the sustainability of corporation debt leverage, and the other is the relationship between corporation debt leverage fluctuations and financial stability.Debt sustainability can be analyzed from both macro and micro perspectives. At the micro level, the sustainability of corporation debt needs to be supported by corporate capital output efficiency. The Inner Mongolia Research Group of the People's Bank of China (2019) analyzed the financial performance of industrial enterprises above designated size from 2003 to 2016 from the perspective of corporate finance (profitability, debt service and asset liquidity indicators), and found that the debt sustainability of state-owned holding companies is not as good as that of private enterprises. It can be seen that the problem of corporation debt structure is not only reflected in the influencing factors, but also has a crucial impact on the sustainability of debt. At a macro level, sustainable corporate sector debt needs to be supported by economic fundamentals. Ma Y and Zhang J (2019) used the TVP-VAR model to examine the time-varying impact of non-financial corporate sector leverage on total output and asset price fluctuations in terms of output effects and potential risks. 
The short- and medium-term effects of output growth are still positive, but the long-term effects are almost zero, which means that in the long run, excessive growth of corporation leverage will increase asset price volatility, increase financial instability, and weaken output growth. With the deepening of finance and the close relationship between the economic and financial systems, the fluctuation of corporation debt leverage not only has an impact within the corporate sector, but also extends to the entire economic and financial system as the balance sheet deepens.

Jiang H and Jiang P (2019) established the relationship between the leverage of the real economy sector and systemic financial risk through the TVP-VAR model, and found that the rise of leverage in the real economy has a positive effect on China's systemic financial risk. In addition, when judging the sustainability of leverage based on the effect of leverage on output, attention should also be paid to the impact of leverage on asset price fluctuations. Schinasi (2003) believes that financial instability is often accompanied by large fluctuations in asset prices. It is both an inducement and a manifestation of financial instability. Liu Xand Shi G (2018) found that there is a positive guiding relationship between the leverage ratio and asset price bubbles,serious leveraged borrowing and continuous growth in investment opportunities will lead to the rapid accumulation of asset price bubbles, asset price bubbles will have a leverage multiplier effect. The accelerated acceleration caused a large-scale default and triggered economic and financial fluctuations.

\section{Conclusion}

After the process of "high leverage", "de-leveraging" and "stabilizing leverage", "structural" has become a new issue of debt leverage in China. Through the above analysis, we recognize that corporate ownership, industries, regions, etc. are all manifestations of corporate debt structure. How to resolve this heterogeneous difference is a problem that must be addressed before us. Under the premise of ensuring the stable operation of the macro economy, how to achieve the balance between "stable leverage" and "stable growth" requires us to understand the reasons for the rise in corporation debt leverage, and systematically analyze the macro environmental factors, financial development factors, and the companies' operating factors. In the life cycle of economic development and enterprise development, debt management is a necessary means, but it also needs to do its best. "Good leverage" can bring capital gains, and "bad leverage" can make it difficult to sustain. Therefore, in the process of "de-leveraging", we need to clarify whether corporation debt leverage is sustainable, whether it is supported by economic growth, and whether it is supported by asset returns. From the perspective of preventing and controlling financial systemic risks, we also need to be concerned about whether corporate debt issues will cause economic fluctuations and financial risks through sector conduction in the process of financial deepening.

Combining previous research findings, the following points about the leverage of China's corporation sector debt have been drawn:The first is to rationally and orderly adjust the debt leverage of the corporation sector. On the one hand, there is heterogeneity in the debt structure of China's corporation sector. This heterogeneity determines that it can't be a one-size-fits-all while "de-leveraging", but should be targeted for adjustment. On the other hand, there are many reasons for the high level of debt in the Chinese corporation sector, from a development perspective, these factors have different degrees of influence at different times. This requires us to look at the issue with a development perspective when dealing with corporation debt leverage. The second is to focus on debt sustainability and financial stability. From the perspective of preventing and controlling financial systemic risks, the performance of debt leverage isto take corresponding measures from the aspect of debt sustainability to form a two-way method of prevention and governance to ensure the stable operation of the macro economy. At the same time, for industries with excessive debt leverage, more attention should be paid to the contagion of systemic financial risks. The third is to fully recognize the linkage of debt leverage among various macroeconomic sectors. As mentioned earlier, under the analysis framework of the macro balance sheet, the linkage effect of various macroeconomic sectors is obvious, and it can be said that the whole body is affected. From a theoretical level, when in-depth research on the impact of various factors on the debt leverage of the corporation sector, it is also necessary to systematically analyze the impact of changes in the external environment on other economic sectors in order to dig deeper into the mechanism of debt leverage.

\section{References}

Cecchetti et al.(2011). The Real Effects of Debt. BIS Working Paper, BIS.

CecchettiS.G, Mohanty M.S, Zampolli F. (2011).The Real Effects of Debt .Social Science Electronic Publishing. 68: 145-196.

Chen D, Shao Y, Yang X. (2018). Rebalancing: Deleveraging and Steady Growth_—Analysis Based on Stock-Flow Consistency Model. Journal of Finance and Economics, 10: 4-23. 
Chen R, ChenS.(2018).Research on the Non-linear Relationship between Corporate Leverage and Economic Growth: A Case Study of Hubei Province, a Typical Central Province.Shanghai Finance, 12: 20-26.

Chen W, XiongQ.(2017).International comparison and countermeasures of leverage ratio of Chinese non-financial enterprises.International Finance Research,2: 3-11.

Dai Y, Peng Y, Ma S.(2018). Understanding the Economic Destabilization from the Micro-perspective: A Review of Related Research on Corporate Finance. Foreign Economics and Management, 11: 31-43.

Deng X.(2015). The Use of Structural Monetary Policy Tools: Practices and Enlightenments of Developed Countries. Southern Finance, 1: 26-34.

Devereux, MichaelB, Yetman, James.(2010). Financial Deleveraging and the International Transmission of Shocks. The International Financial Crisis and Policy Challenge In Asia and the Pacific. 52: 274-298.

Hong C, Xu C.(2010). Debts of Chinese Non-financial Corporations: Influencing Factors, Dynamic Characteristics and Handling Strategies-Based on "From General to Special" Dynamic Modeling Methods. Comparison of Economic and Social Systems, 5: 35 -46.

Huang J, Li X.(2018).Research on Non-financial Enterprise Sector Leverage and Banking Risk. Financial Supervision Research, 2: 40-54.

Huang Z.(2013). Differences in leverage ratios of various sectors of China's national economy and policy suggestions. International Finance, 1: 51-53.

Hu Z.(2014). Setting the Optimal Policy of the Monetary Authority under the Dual Goals of "Stable Growth" and "Leverage Control".Economic Research Journal, 12: 60-71.

GH Bauer, E Granziera.(2017). Monetary Policy, Private Debt and Financial StabilityRisks. International Journal of Central Banking, 13: 337-373.

Gou W, Yuan Y, Qi X. (2016).Debt leverage and systemic risk contagion mechanism: analysis based on CCA model .Journal of financial research, 3: 74-89.

Ji M, Li H, Yang X.(2018).Leverage Level, Economic Structure Transformation and "Debt-deflation" Risks. Macroeconomic Research,1.

Ji M, Yan B, Li H.(2017). Leverage Structure, Level and Financial Stability_- Theoretical Analysis Framework and Chinese Experience.Financial Research, 2: 11-25.

Jiang H, Zhang Y.(2017).Analysis on the status quo and influencing factors of China's non-financial enterprise sector debt. China Development, 4: 6-11.

Li Y.(2016).Comprehensive deliberations of "deleveraging”. China Economic Report,10: 83-85.

Li Y, Zhang X, Chang X.(2015). China's National Balance Sheet 2015: Leverage Adjustment and Risk Management. Beijing: China Social Science Press.

Liu W, Wang H.(2017). Corporate Leverage, Economic Growth and Asset Price Fluctuations: An Empirical Analysis Based on MS-VAR Model. Economic Theory and Practice,7: 117-120.

Liu L, Ma S.(2018). Financial crisis, shadow banking and debt problems. Journal of Nankai University (Philosophy and Social Sciences Edition), 2: 42-49.

Liu X, Liu Y, Wang J.(2018). Leverage, Economic Growth and Recession. Social Sciences in China, 6: 50-70.

Liu X, Zhang J.(2016). China 's Paradox of Leverage: Also on the Dilemma of "Stable Growth" and "Leverage Reduction" of Monetary Policy?Finance and Trade Economy, 8: 5-19.

Liu J, Chen D.(2017). Understanding China's Monetary Policy Regulation Model: "Stable Leverage" or "Leverage Reduction"? —_Empirical Research Based on TVP-VAR Model.Journal of Xi'an Jiaotong University (Social Science Edition), 11: 1-8.

Liu X, Niu M, Yang Y.(2009). Analysis of Chinese Residents' Balance Sheet. Financial Research, 10

Liu Y.(2018). A Study of the Impact of Monetary Policy on the Macro Leverage Gap. Economics and Economics Series, 6: 46-54.

Lu L, Deng X.(2015). International Comparison and Enlightenment of Structural Monetary Policy Tools. World Economic Research, 6: 3-11.

Luo Y, Chen B.(2018). The Shock Effect of Monetary Policy under High and Low Leverage and the Stability of Monetary Policy in the Process of Deleveraging__ Test of Financial Accelerator Effect Based on DSGE Model. Finance and Trade Research, 8: 62-74.

Ma J, Dong X, Shi H, etc.(2016). China's leverage ratio and systemic financial risk prevention.Finance and Trade Economy, 1: 5-21.

Ma Y, Chen Y.(2017). Financial leverage, leverage fluctuations and economic growth. Economic Research, 6: 31-45.

M.D.Odom, R.Sharda.(1990).A neural network model for bankruptcy prediction. International Joint Conference on Neural Networks, 2: 163-168. 
Moritz S, Alan M. Taylor.(2008). Credit Booms Gone Bust: Monetary Policy, Leverage Cycles, and Financial Crisis: 1870-2008. NBER Working Paper.

Pan Z.(2018). Logistic regression early warning model of corporate debt default risk. Shanghai Economic Research, 8: 73-83.

P Benignop, GB Eggertsson, F Romei.(2015). Dynamic Debt Deleveraging and Optimal Monetary Policy. NBER Working paper, 2015.

Peng G, Zhang C.(2019). Research on the Rationality Evaluation and Adjustment Path of Non-financial Enterprises' Leverage Ratio.Economics and Management, 2: 61-67.

Peng Y, Fang Y.(2016). Structural monetary policy, industrial structure upgrade and economic stability. Economic Research.7: 29-42.

Porta, Rafael La, et al.(1998). Law and Finance. Journal of Political Economy: 1113-1155.

Reinhart, Rogoff.(2011). From financial crash to debt crisis. American Economic Review. 5: 1676-1706.

Song G.(2013). Looking at China's Investment and Monetary Policy from the Ratio of Monetary Output to Capital Output.China Market, 19: 10-15.

Song G.(2014). The interest rate is a car. The exchange rate is Ma. Beijing: Peking University Press: 33-35.

Song M, Hu Y.(2017). Micro-mechanism and Systematic Impact of Risk Transmission among Economic Sectors-A Study Based on the Balance Sheet Analysis Method. Journal of Fujian Institute of Financial Management, 1: 23-32.

Tan X, Li Y, Wang K.(2019). Financial Structure and "Deleveraging" of Non-financial Enterprises. China Industrial Economy,2: 23-41.

Tan X, Li Y.(2018). Debts of Non-financial Enterprises in Emerging Market Countries: Status Quo, Causes, Risks and Countermeasures. International Economic Review, 5: 61-77.

Timothy G.(2002). Assessing Sustainability. IMF Working Paper, IMF.

Wang A, Du Q.(2018). Stabilizing growth and reducing leverage: How to choose the central bank's monetary policy under the policy paradox. Journal of Tianjin University of Finance and Economics, 3: 27-36.

Wang G, Guo J.(2018).Heterogeneity Estimation, Future Scenario Simulation and Empirical Study of Leverage Ratio of Chinese Non-financial Enterprises. Economic Survey, 6: 158-164.

Wang W. (2018).Structural monetary policy, corporate financing cost and investment scale. Financial Theory and Practice, 9: 17-20.

Wang Y, Yang Y.(2016).Causes and Governance of China's High Leverage. Southern Finance, 1: 5-9.

$\mathrm{Wu}$ J, Chen L.(2018). The relationship between the degree of financialization of non-financial companies and changes in leverage-Evidence from A-share listed companies and bond-issuing non-listed companies. Financial Forum, 1: 3-15.

Wu Y, Du Q.(2018). Theoretical and empirical research on the formation mechanism of China's debt leverage. Journal of Nankai University (Philosophy and Social Sciences Edition), 5: 152-160.

Wu Z, Lu Y, He H.(2018).Research on the Spillover Effect of the Financing Structure of Real Enterprises on Financial Market Risks. Financial Supervision Research,11: 65-79.

Xiao Q.(2010).Liquidity, Leverage and Financial Stability. Research on Financial Development, 9: 9-14.

Xu Y.(2014).Research on the leverage of China's non-financial enterprises. Finance and Economy, 10: 38-41.

Xu Z.(2018).Transformation of China's currency regulation and control mode at the stage of high-quality economic development. Working Paper of the People's Bank of China,3.

Yang J, Gao H.(2016).International Comparison and Path Choice of "Adding and Subtracting Leverage" of Industries. Journal of Shanxi University (Philosophy and Social Science Edition), 6.

Yang G.(2018).Research on Structural Problems of Leverage Ratio of Chinese Non-financial Enterprises. Economics and Management, 2: 63-69

Yang G.(2018). Research on the Impact of High Leverage on Chinese Non-financial Enterprises_—Based on the Perspective of Financing Model. University of International Business and Economics.

Yang S, Wang Z, Wu P.(2019).Research on the Value Governance Effect of Debt Maturity Structure and Debt Instrument Structure under the New Normal Background. Mathematical Statistics and Management, 5.

Yuan G, Guo C.(2019).Empirical Study on the Impact of Corporate Financialization on Excessive Liabilities of NonFinancial Enterprises. Statistics and Decision, 11: 164-167.

People's Bank of China Leverage Research Group.(2014).China's Economic Leverage Level Evaluation and Potential Risk Study. Financial Supervision Research, 5: 23-38.

Public People's Bank of China Hulunbuir City Sub-branch.(2019).Research on Debt Sustainability of Chinese Nonfinancial Enterprises. North China Finance, 2: 34-48. 
Zhao L.(2018).Research on the leverage and risk of China's financial, corporate and government departments. Jilin University, 2018.

Zhang X, Wen F.(2018).Structural deleveraging: policy evolution, theoretical logic and implementation path. Reform, 8: 5-14.

Zou Z.(2018).The Connotation, Performance and Governance of Economic Finance: A Literature Review. Southern Finance, 2: 20-30.

Zhong N, Liu Z, He J, Su C.(2016).Structural Problems of Chinese Enterprise Debts. Economic Research, 7: 102-117.

Zhou J, Wang Y, Han X.(2018). Deleveraging, Turning Leverage and Monetary Policy Transmission: A Study Based on New Keynes Dynamic General Equilibrium.International Finance Research, 4: 24-34.

Zhu T.(2018). China's Real Economy Debt: Evolution, Risk and Governance. Journal of Dongbei University of Finance and Economics, 5: 71-81. 